Assiut Regional Vet. Laboratory

Institute of Animal Health Research

Head of Dept. Prof. Dr. S.M. Nashed.

\title{
STUDIES ON YERSINIA ENTEROCOLITICA \\ MICRO-ORGANISM IN SOME MEAT \\ PRODUCTS
}

(With 3 Tables)

By

\section{A.A. ABOU EL ELA}

(Received at 29/10/1994)

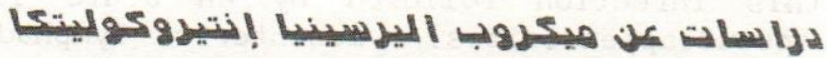 Aglll تصن

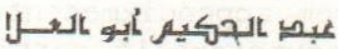

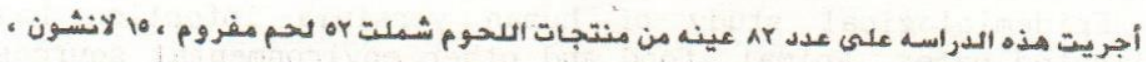

ما بسمرمه جمعت من السوبر ماركت المختففه بمدينة أسيوط كمبرفة مدى تواجد ميكروب

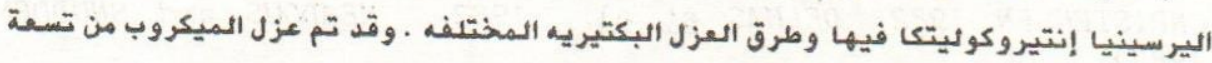

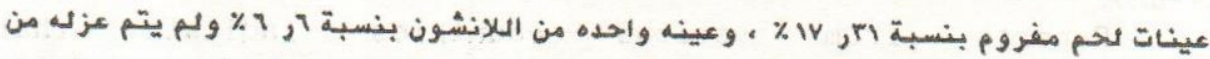
ألبسطرمه وقد تم تمنيف المميكروب بيوكيميائيا بنوع ع وقد تمت مناقثة النتانج وأهمية

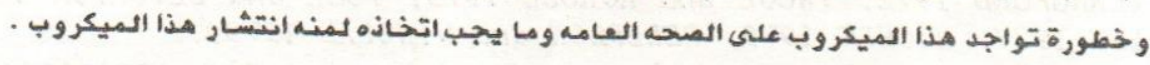




\section{A. A. ABOU EL ELA}

\section{SUMMARY}

A total of 82 random samples ( 52 minced meat, 15 lunchon and 15 basterma) from different suppermarkets in Assiut City were examined for the occurrence of yersinia enterocolitica by different methods. The organism was isolated from 9 samples of minced meat (17. $31 \%$ ) and one sample of lunchon $(6.6 \%)$. All isolates belonged to biotype 4 . The importance of $Y$ enterocolitica as a public health hazard was discussed.

Keywords: Studies, Yersinia Enterocolitica, meat products.

\section{INTRODUCTION}

yersinia enterocolitica infection of the gastrointestinal tract have increasingly been reported in human during the past decade (BOTTONE 1977, KHOL et al., 1977, BLAK et al., 1978; CAPRIOLI et al., 1978). Acute gastroentritis is the most frequent clinical from of this infection followed by an acute iliac fossa syndrome (pseudoappendicitis), mesenteric lymphadenitis or tereminal ileitis). Other clinical conditions described are septicemia, polyarthritis, erythema nodosum and abscesses (TOMA AND LUCETTE 1974). The organism is usually isolated from fasces and less frequently from appendixmesentric lymph nods, abscess blood, urine and fromasymptomatic carrier (SCHIEMANN and TOMA 1978).

Epidemiological study of human yersinia infection has implicated water, animal, food and other environmental sources as reservoir of the organism (MORRIS and FEELEY 1976, LEE 1977, CHRISTENSEN 1982, DELMAS et al., 1982, MEADOWS and SNUDDEN 1982).

Reports from various countries indicate that $Y$.enterocolitica is commonly found in various animal species (LANGFORD 1972, INOUE and KUROSE 1975, TOMA and DEIDRICK 1975, LEE 1977, HUGHES 1979, PEDERSON and WINBLAD 1979).

The aim of our study was to determine the incidence of Y.enterocolitica in some meat products (minced meat, luncheon, basterma) by compartive study on different media for isolation and the role of the organism as a public health hazard.

Assiut Vet. Med. J. Vol. 32 No. 63, October 1994. 


\section{MATERIAL AND METHODS}

\section{Collection and Preparation of Samples:}

Samples of meat products included ( 52 minced meat, 15 luncheon and 15 basterma) were collected from different supermarkets in Assiut city in sterile plastic bags. The samples were transferred in freeze box to the laboratory with a minimum of delay.

Isolation of Y.enterocolitica:

A-11 gm of each sample was placed in a sterile flask, containing $99 \mathrm{ml}$ of selenite broth then incubated at $37^{\circ} \mathrm{C}$ for 18 hours. From the selenite broth, a loopfull was in-oculated into S.S agar and cefsulodin-Irgasan-Novobiocin (CI N) agar which incubated at $37^{\circ} \mathrm{C}$ for $24-48$ hours. The colony having the morphological character of Y.enterocolitica was picked up and streaked into slope agar to be subjected for further identification.

B-One gram of each sample was thourghly mixed and transferred to $10 \mathrm{ml}$ phosphate buffer saline (PBS, $M / 15$, PH.7.6) which incubated at $4^{\circ} \mathrm{C}$ for 14 days for enrichment. Enrichment samples were inoculated into cefsulodin-Irgasan -Novobiocin (CIN) agar (oxoid) (SCHIEMANN 1979 a, 1979b) and S.S. agar and incubated at $37^{\circ} \mathrm{C}$ for $24-48$ hours.

The criteria used for presumptive idintification of Y.enterocolitica was a colony having a deep red center "bulleye" surrounded by a transpatent border. The edge of the colony was entire or irregular. All presumptive colonies were transferred to nutrient agar slant and stored after incubation at $32^{\circ} \mathrm{C}$ for 24 hours in a refrigerator at $4^{\circ} \mathrm{C}$ for later biochemical reactions as shown in table 1. (SCHIEMANN and DEVENISH, 1982), which revealed that the reaction on kligler iron agar, together with tests for urea hydrolysis, and sucrose and salicin fermentation are sufficient for differentiating Y.enterocolitica from other organisms that are capable of growing on CIN medium and also for distingushing pathogeneic forms.

The strains were biotyped according to WAUTERS (1970), Table 2 .

\section{RESULTS}

The obtained results are summerized in Table (3). 


\section{A. A. ABOU EL ELA}

\section{DISCUSSION}

Human infection due to Y.enterocolitica have now been reported in numerous countries all over the world. There has been a steady increase in the number of countries which report this infection. In spite of these facts, knowledge of the geographical distribution of this organism is still fragmentary.

The results of this study showed that the incidence of Y.enterocolitica among the examined samples of meat products (Minced meat, Luncheon, Basterma) were $17.31 \%, 6.6 \%$ and $0.0 \%$ respectively. This rate is nearly similar to those recorded by HANNA et al. (1976) which isolated Y.enterocolitica from vaccum paeckaged beef and lamb also to those studies of SCHIEMANN (1980) who isolated Y.enterocolitica from a sample of ground pork $10.8 \%$ ). ANDERSON et al., (1991) detected Y.enterocoliticea in 3 out of 24 samples of minced meat $(12.5 \%)$ on the other hand. ABDEL ALL (1993) isolated Y.enterocolitica from minced meat, luncheon, basterma in a rate of $10.34 \%, 0.0 \%, 0.0 \%$ respectively. The failure of isolation of Y.enterocolitica from luncheon and basterma may be due to the fact that curing process play a great effect on the survival and multipication of the microorganism. The presence of nitrates has also a bacterostatic effect on the microorganism (CASTELLANI et a., 1955 and Libby 1975). Furthermore, the organism failed to be detected in the examined luncheon and basterrma as the result of garlic content on its surface which as a bacteriocidal or bacteriostatic effect on the microorganism (VORLLRATH et al., 1977).

From table 3 , it was shown that the incidence of isolation of Y.enterocolitica after cultering in phosphate buffer saline then inoculation on CIN agar plates is more than that culturing in selenite borth and inoculation on S.S. agar. These results is similar to those reported by MARTIN and WASHENGTON (1980), SACK et al. (1980) they noticed that none of the usual enteric plating media used for enterobacteriaceae is highly selective or differential for Y.enterocolitica such as S.S. agar which will not grow all strains. SCHIEMANN (1979) concluded that CIN agar media was more selective than S.S. agar.

The difference in these results may be attributed to the incorrect hygienic measures during preparing and processing of these products, also to various temperatures used in storing the products as freezing to $-18^{\circ} \mathrm{C}$ and $-75^{\circ} \mathrm{C}$ resulted in $7 \%$ and $42 \%$ cell inactivation respectively (GREEZ and EL-ZAWAHRY, 1984). 
As the refrigeration is commonly used in food stores and private home to prolong the time of storage of perishable food, this treatment gives a reasonable protection against the multiplication of a number of pathogens. Y.enterocolitica however, is one of the few human pathogen which is able to grow at refrigerator temperature (NILEHN, 1969 and WAUTERS, 1970); (ZEN-YOJI et al., 1974). So refrigeration favour the growth of Y.enterocolitica analagous to the cold enrichment procedure used in isolation of microbial group.

BOYCE et al. (1979) showed, that Y.enterocolitia enterotoxin is an acid stable and is not inactivated by exposure to $120 \mathrm{C}_{1} / 2$ for 30 minutes or by storage at $4 \mathrm{C}_{1 / 2}$ for at least 5 months. They suggested that this toxin is able to with stand gastric acidity and temperature used in food processing and storage. Thus, performed enterotoxin may be capable of causing food-borne intoxication Health and Welfare Canada 1976 and BLACK et al., 1978). So the contamination of meat products with Y.enterocolitica during prepaing and processing suggests that attention to hygienic handling practices may be an important preventive measures. Likewise using freezing (not chilling) as well as proper heat treatment would eliminate the risk of infection by this organism.

\section{REFERENCES}

Abdel A11, F.A. (1993): Contamination of meat products with human pathogens. M.V.Sc. Bact. Ass.

Anderson, J.K.; Sorensen, R. and Glensbjerg, M. (1991): Epidemological studies of yersiniosis. Int. J. FoodMicrobiolo. (1991) Jul. 13(3) 271.

Black, R.E.; Jackson, R.J.; Tsai, T. Medvesky, M.; Shayegani, M.; Feely, T.C.; Macleod, K.I.E. and Wakellee, A.M. (1978): Epidemic yersinia enteocolitica infection due to contaminated chocolate milk. New Engl. J. Med. 298: 76-79.

Bottone, E.J. (1977): Yersinia enterocolitica. A panoramic view of a charismatic micro-organism. Critical Reviews in Microblology 5: 211-241.

Boyce, J.M.; Evans, D.J.; Evans, D.G. and Dupont, H.L. (1979): Production of heat stable methanol soluble enterotoxin by yersinia enterocolitica. Infection and Immunity 25: 532-537.

Caprioli, T.; Drapeau, A.J. and Kasatiya, S. (1978): Yersinia enterocolitica serotypes and biotypes isolated from humans and the environment in Quebes, Canda Journal of Clinical Microbiology 8: 7-11. 
Castellani, A.G. and Niven, C.F. J.R. (1955): Fait or affecting the bacteriostatic action of sodium nitrate. Appl. Microbi., 11: 488-500.

Christensen, S.G. (1982): The prevalence of Yersinia enterocolitica in slaughter animals, water and raw milk in Denmark.

In Psychrotrophic Microorganism in spoilage and pathogenicity Ed. Robert, T.A. Hobbs, G. Christian. J.H.B. and Skovgaard, N. London: Academic press.

Delmas, C.L.; Vidon, D.J.M.; Woerth, A. and Wolf. D. (1985): Yersinia enterocolitica in food, meat products, raw vegatables, cakes and ice-cream. Science des Aligments. 5: 73-79 Dairy Sci. Abst. (1986) 78(1) 254.

Hanna, M.O.; Zink, D.L.; Carpenter, Z.L. and Vanderzant, C. (1976): Yersinia enterocolitica-like organism from vaccum packed beef and lamb. J. Food. Sci. 41: 1254-1256.

Health and Welfare Canada (1976): Yersinia enterocolitica gastroentritis out break, Montreal (correction). Can. Dis. Weekly Rep. 2: 73-74.

Hughes, D. (1979): Isolation of Yersinia enterocolitica from dairy farm in Australia. J. of Applied Bacteriology 46: 125-130.

Inoue, M. and Kurose, M. (1975): Isolation of Yersinia enterocolitica from cow's intestinal content and beef. Japaness J. Vet. Sci. 37: 91-93.

Greez, N. and El-Zawahry, Y.A. (1984): Effect of radiation and freezing on $\left(\mathrm{H}^{3}\right)$ DNA of Yersinia enterocolitica. Appl. Environ. Microbiol., 47: 1101-1105.

Khol, S.; Jacobson, J.A. and Nahmias, A. (1977): Yersinia enterocolitica infection in children. Journal of Microbiology 23: 1714-1722.

Langford, E.V (1972): Yersinia enterocolitica isolated from animal in the Freser Valley of British Columbia Canadian Veterinary Journal 13: 109-113.

Lee, W.H. (1977): An assessment of Yerscinia enterocolitica and its presence in food. J. Food. Prot. 40: 486-489.

Libby, J.A. (1975): Meat Hygiene 4 th Ed. LEA and FEBIGER, Philadelphia.

Martin, W.J. ad Washington, J.T.A. (1980): Enterobacteriacae. In Manual of Clinical microbiology. $3^{\text {rd }}$ Ed. Edited by R. H. Lenette, A. Balows, W. T. Hausler, Jr. and J.P. Truant. American Society for microbiology, Westington, DC., pp. 195-219.

Meadows, C.A. and Snudden, B.H. (1982): Prevalence of yersinia enterocolitica in water of lower chippewe River Basin, Wisconsin. Appl. Enviro. Microbiol. 43: 953-954.

Assiut Vet. Med. J. Vol. 32 No. 63, October 1994. 
Morris, G.K. and Feeley, J.C. (1970): Yersinia enterocolitica, a review of its role and food hygiene. Bull. Co. H.0. 54: 79-85.

Morris, G.K. and Feeley, J.C. (1976): Yersinia entercolitica a review of its role in food hygiene. Bull of W.H.O. 54: 74-85.

Nilehn, B. (1969): Studies on yersinia enterocolitica with special reference to bacterial diagnosis and ocurrance in human acute enteric disease. Acte patho. Microbiol. Scand., Supp. 206.

Pederson. K.B., Winbled, S. (1979): Studies on Yersinia enterocolitica isolated from swine and dogs. Acta pathologica et Microbiologica Scandinavica Section B 87: 137-140.

Sack, R.B. ; Tilton, R.C. and Weissfeld, A.S. (1980): Laboratory diagnosis of bacterial diarrhea. Cumitech 12. American Society for microbiology, Washington, D.C.

Schiemann, D.A. and Toma, S. (1978): Isolation of Yersinia enterocolitia from raw milk. Appl. Environ. Microbiol. 54-58.

Schiemann, D.A. (1979a): Envirchment methods for recovery of Yearsinia enterocolitica from foods and raw milk. In contributions to Microbiology and Immunology Vol. 5-Yersinia enterocolitia: Biology. Epidemiology and pathology. pp. 212-217. Basel: Karger.

Schiemann, D.A. (1979b): Synthesis of selective mediun for Yersinia enterocolitica. Can. J. Microbiology 25, 1298-1304.

Schiemann, D.A. (1980): Isolation of toxigenic Yersinia enterocolitica from retail pork product. J. of Food protection 43: 360-365.

Schiemann, D.A. and Devenish, J.A. (1982): Cited after oxoid (1982): The oxid manual of culture media, ingredients and other laboratory services. Oxoid manual limited, 5 th $\mathrm{Ed}$. Hampshire England.

Toma, S. and Lucette, L. (1974): Survey of the incidence of Yersinia enterocolitica infection in canada. Appl. Microbology 28: 409-473.

Toma, S. and Deidrick, V.R. (1975): Isolation of Yersinia entrocolitica from swine. Journal of Clinical Microbiology 2: 478-481.

Vorllrath, R.E.; Walton, L. and Lindergren, C.C. (1977): Proc. Soc. Exp. Biol. Med., 36-55 (Cited after Faisal (1993). Contamination of meat and meat products with human bacterial pathogens (M.V.Sc.) Fac Vet. Med. Assiut University. 


\section{A. A. ABOU EL ELA}

Wauters, G. (1970): Contribution aletude of Yersinia enterocolitica. These d'agregation Vander, edit. Bruxelles, Louvain.

Zen-Yoji, H.; Sakal, S.; Maruyama, T. Yanagawa, Y. (1974): Isolation of Yersinia enterocolitica and Yersinia pseudotuberclosis from swine, Cattle and rats at an abattoir. Jap. Journal of microbiology 18: 103-105.

Table (1): Typical reactions of pathogenic Yersinia enterocolitica

\begin{tabular}{||l|c|c||}
\hline \multicolumn{1}{|c|}{ Test } & Incubation Temperature & Test Result \\
\hline \hline Kliger Iron Agar & $35 \mathrm{C}^{\circ}$ & $\begin{array}{c}\text { Alkaline/acid but no gas } \\
\text { or H25 positive }\end{array}$ \\
\hline Urea hydrolysis & $35 \mathrm{C}^{\circ}$ & Positive \\
\hline Sucrose fermentation & $22 \mathrm{C}^{\circ}$ & Positive \\
\hline Salicin Fermentation & $35^{\circ} \mathrm{C}$ & Negative \\
\hline
\end{tabular}

Table (2): Wauters biotyping of Yersinia enterocolitiea

\begin{tabular}{|l|l|l|l|l|l|}
\hline & 1 & 2 & 3 & 4 & 5 \\
\hline \hline Lecithinase & + & - & - & - & - \\
\hline Indole- & + & + & - & - & - \\
\hline Trehalose & + & + & + & + & - \\
\hline
\end{tabular}

Table (3): Incidence of Yersinia enterocolitica in some meat products.

\begin{tabular}{|c|c|c|c|c|c|c|c|c|c|c|}
\hline \multirow{4}{*}{$\begin{array}{l}\text { Type of } \\
\text { Sample }\end{array}$} & \multirow{4}{*}{$\begin{array}{c}\begin{array}{c}\text { No. of } \\
\text { examind }\end{array} \\
\text { Sample }\end{array}$} & \multicolumn{8}{|c|}{ Number of Positive } & \multirow{4}{*}{ Biotyping } \\
\hline & & \multicolumn{4}{|c|}{ Selenite Broth } & \multicolumn{4}{|c|}{ Phosphate Buffer Saline } & \\
\hline & & \multicolumn{2}{|c|}{ S.S. Agar } & \multicolumn{2}{|c|}{ CIN Agar } & \multicolumn{2}{|c|}{ S.S. Agar } & \multicolumn{2}{|c|}{ CIN Agar } & \\
\hline & & No. & $\%$ & No. & $\%$ & No. & $\%$ & No. & $\%$ & \\
\hline Minced meat & 52 & $\overline{6}$ & 11.54 & 3 & 5.8 & 2 & 3.8 & 9 & 17.31 & 4 \\
\hline Luncheon & 15 & 0 & 0 & 0 & 0 & 0 & 0 & 1 & 6.6 & 4 \\
\hline Baslerma & 15 & 0 & 0 & 0 & 0 & 0 & 0 & 0 & 0 & - \\
\hline
\end{tabular}

